\title{
FEEDING ECOLOGY OF FIVE NEOTROPICAL UNGULATES: A CRITICAL REVIEW
}

\author{
Helbert Medeiros Prado \\ University of São Paulo, Institute of Biosciences, Department of Ecology, Laboratory of Human Evolution Studies, Matão Str. 277, São Paulo, SP, \\ Brazil. CEP: 05508-090. \\ E-mail: helbertmedeiros@yahoo.com.br
}

\begin{abstract}
In addition to shedding light on underlying ecological processes, studies about animal diets are useful for guiding the design of species conservation projects. This study presents general characterizations of the diets of five neotropical ungulates, the lowland tapir (Tapirus terrestris), the red brocket deer (Mazama americana), the grey brocket deer (Mazama gouazoubira), the collared peccary (Pecari tajacu) and the white-lipped peccary (Tayassu pecari). In addition, a critical review of methodological procedures used in this field of ecology is presented. A number of methodological limitations were identified in this review, which may help guide future research in this field. The predominant types of studies reviewed focused on analyses of fecal matter and stomach contents. Direct observation of foraging, while difficult to implement, has revealed interactions among ungulates and other mammals that are otherwise difficult to observe. The general foraging patterns of various species and the main ecological roles of the species in the various environments where they occur were also observed. A list of plant species and families is also presented here to aid researchers and conservation practitioners in accessing resources about the main items in the ungulate diets discussed in this study.
\end{abstract}

Key words: Fauna; Diet; Methods; Foraging Patterns; Large Mammals.

\section{RESUMO}

Além de revelar processos ecológicos subjacentes, estudos sobre a dieta de espécies da fauna também geram informações úteis para o delineamento de projetos visando a conservação das mesmas. Esta revisão apresenta uma caracterização geral da dieta de cinco ungulados neotropicais, a anta (Tapirus terrestris), o veado mateiro (Mazama americana), o veado catingueiro (Mazama gouazoubira), o cateto (Pecari tajacu), e o queixada (Tayassu pecari), juntamente com uma avaliação crítica dos procedimentos metodológicos que têm sido adotados nesse campo do conhecimento ecológico. Algumas limitações metodológicas foram identificadas, o que pode servir de base de reflexão para pesquisas futuras nessa área. As análises do conteúdo fecal e estomacal predominaram entre os estudos. Já o método de observação direta do forrageio, apesar da sua difícil aplicação, foi ímpar ao revelar interações entre ungulados e outros mamíferos ainda pouco conhecidas da Ciência. Padrões gerais no forrageio das espécies também foram evidenciados, assim como os principais papéis ecológicos que as mesmas podem desempenhar nos diferentes contextos ambientais em que ocorrem. Uma lista de espécies e famílias botânicas também é apresentada, e visa facilitar o acesso de pesquisadores e de ambientalistas aos recursos que até o momento são tidos como os principais itens da dieta desses animais.

Palavras-chave: Fauna; Dieta; Métodos; Padrões de Forrageio; Mamíferos de Grande Porte.

\section{INTRODUCTION}

This paper presents a critical review of literature on the diets of five species of Neotropical ungulates (Tapirus terrestris, Mazama americana, Mazama gouazoubira, Pecari tajacu and Tayassu pecari). The ungulates mainly display frugivorous, granivorous, folivorous and grazing habits (Eisenberg \& Redford 1999). They may act as seed predators or dispersers or as seedling predators (Howe \& Smallwood 1982), and they often help control the growth and primary productivity of herbaceous and woody elements in different ecosystems (McNaughton et al. 1988, Augustine \& Frelich 1998).

The wide geographic range, relative adaptability to anthropogenic environments and high mobility of this group of ungulates (Eisenberg \& Redford 1999) also makes it possible to assess the ecological implications of these species' feeding habits and diet on landscape dynamics, at both the local ecosystem and biome scales. In fact, it has already been empirically shown that the abundances of these species have direct and indirect effects on the population dynamics, structure and composition of plant communities in the Neotropics (Terborgh \& Wright 1994, Asquith et al. 1997) and other regions (Stoner et al. 2007).

In addition to hunting, the main threats to the Neotropical ungulates are habitat degradation, loss and fragmentation (Cullen et al. 2000, Robinson \& Bennett 
2000, Peres 2001). Habitat fragmentation not only isolates local populations but also directly affects the amount of plant food resources available for ungulate populations by reducing plant species richness (Collinge 1996). The predominance of secondary forests in tropical regions and their effects on regional fauna have also been widely discussed in the conservation literature (DeWalt et al. 2003, Wright \& Muller-Landau 2006, Bowen et al. 2007, Gardner et al. 2007, Prado et al. 2014). Further investigation of the foraging patterns of animals in these novel environmental contexts is needed. The widespread habitat modification and fragmentation occurring in the Neotropics points to a need for additional ecological studies that address current environmental conditions and are based on improved, high-quality research methods, such as standardized and independent observations.

Accordingly, the specific objectives of this review were the following: (1) to record and compare the number of samples used by these studies (i.e. number of feces, stomachs, and/or foraging observation events) and the spatial and temporal coverage of data collections; (2) to characterize the species' diets in this group; (3) to list the most commonly consumed plant species and families in the different biomes where the species occur; and (4) to identify the ecological processes underlying the group's diets as well as to discuss their implications for conservation.

\section{METHOD}

\section{Methods for the Literature Search and Analysis}

This review was restricted to studies that characterized species' diets in a systematic manner, as opposed to more general observations of foraging habits. In addition, only studies involving in situ data collection with direct evidence of consumption were included in the review. Literature was obtained through a search in the ISI Web of Science database (http:// www.isiwebofknowledge.com) with the following combination of terms for each species: "species" scientific name" and (diet or feeding ecology or feeding habits or nutrition or foraging ecology or food niche or foraging behavior). The same search was then repeated using the species' common name. Therefore, 14 combinations of terms were used for each of the five study species. The searches were performed without specifying the time period during which the studies were published.
Files that could not be obtained in digital format from the ISI Web of Science platform were obtained from the http://scholar.google.com website or from the Universidade de São Paulo (USP) online and physical journal collection (http://www.usp.br/sibi/). Finally, the Tapir Specialist Group (TSG) library (http:// atrium.tapirs.org/) was consulted to refine the search for studies on the lowland tapir. Only journal articles and book chapters were considered. The search was performed in 2010, updated in 2013, and returned a total of 127 studies. Following the examination of its objectives and methods, only 68 studies matched with criteria of inclusion herein adopted.

The analysis unit used in this review was the "diet record," which represented the data collected on the diet of each ungulate at a given study site. This unit was independent of the number of papers produced from the same data in the diet record. The review is structured as follows. First, the methodological aspects of the studies are discussed. Second, the diet of each animal is characterized in terms of the relative importance of different parts of the plants consumed. Finally, the species' foraging patterns are presented, and the ecological aspects of their diets are discussed.

\section{General Characteristics of the Study Species}

The lowland tapir (T. terrestris) is the largest Neotropical terrestrial mammal, is generally solitary and is found at low densities (Eisenberg \& Redford 1999). Given its relatively low reproductive rate, hunting has been one of the main threats to the survival of this species in recent decades (Bodmer et al. 1994). Tapirs have extensive home ranges ranging from 150 ha to 400 ha (Tobler et al. 2009), which also makes this species highly vulnerable to habitat loss and fragmentation. Regarding diet, the lowland tapir feeds mostly on fibrous vegetative plant material but also ingests many fruits and seeds (Barcelos et al. 2013).

The red brocket deer (M. Americana) is found from southern Mexico to northern Argentina and is more common in forests and wet areas, whereas the grey brocket deer (M. gouazoubira) is also common in open and dryer areas and is found from Panama to northern Argentina (Eisenberg \& Redford 1999). The home range of these cervids may reach approximately 100 ha (Maffei \& Taber 2003). With relatively high population recruitment rates, these species are among the group of Neotropical large mammals least affected by hunting (Robinson \& Redford 1986, Robinson \& Bennett 2000). 
The collared peccaries $(P$. tajacu $)$ are the most widely distributed Neotropical ungulates, occurring from the southern U.S. to northern Argentina. They live in groups of up to 50 individuals (Judas \& Henry 1999). This species' home range may vary between 10 ha and 1000 ha (Taber et al. 1994, Judas \& Henry 1999, Carrillo et al. 2002, Keuroghlian et al. 2004). White-lipped peccaries (T. pecari) form large groups of 50 to 400 individuals (Altrichter \& Almeida 2002, Keuroghlian et al. 2009) and move over large distances (up to $13 \mathrm{~km}$ per day). Their home ranges vary from 1000 ha to 10,000 ha (Kiltie \& Terborgh 1983, Bodmer 1990, Fragoso 1998, Fragoso 1999, Altrichter \& Almeida 2002, Carrillo et al. 2002, Keuroghlian et al. 2004, Jácomo et al. 2013). The collared and whitelipped peccaries have similar diets but occupy different habitats (Bodmer 1991a) or exploit the landscape on different spatial scales (Fragoso 1999). Both species use the strength of their jaws to break open hard seeds and are able to break down the seeds by fermentation in their stomachs (Bodmer 1991b).

\section{RESULTS AND DISCUSSION}

\section{Sampling Design and Procedures Used in the Studies}

A total of 68 published studies (53 diet records in the field) were analyzed in this review. The studies were published between 1959 and 2013. The review included 15 diet records for the lowland tapir, eight for the white-lipped peccary, 17 for the collared peccary, four for the red brocket deer and nine for the grey brocket deer (Figure 1). The studies were performed in 13 countries from the southern U.S. to northern Argentina. Desert (Arizona, USA) and arid (southern Texas, USA) areas were represented in the studies, in addition to
Tropical Rain Forest (Atlantic Forest, Amazon, Brazil/ French Guiana), Semideciduous Tropical Forest, Chaco Forest (Argentina), Deciduous Tropical Forest (Mexico), Pantanal (Brazil) and transition areas between Semideciduous Forest and Cerrado (Brazil).

Only 29 diet records (55\% of the total records) reported the size of the area where the study was performed. The size of the study areas varied from 200 ha to $1,523,400$ ha. The size of the effective sampling area within the study area (area where feces and stomachs were searched and foraging direct obervations were performed) was only reported in five diet records (10\%) (Salas \& Fuller 1996, Fragoso \& Huffman 2000, Kufner et al. 2008, Talamoni \& Assis 2009, Serbent et al. 2011) (Table 1), ranging from 1500 $\mathrm{m}^{2}$ to $82,500 \mathrm{~m}^{2}$ in size (mean= $=51,000 \mathrm{~m}^{2}$, standard deviation $=30,019 \mathrm{~m}^{2}$ ).

In addition, only nine records (17\%) specified the number of sampling sites per ecological unit on the landscape studied (Eddy 1961, Salas \& Fuller 1996, Henry et al. 2000, Santos et al. 2005, Kufner et al. 2008, Talamoni \& Assis 2009, Serbent et al. 2011, Hibert et al. 2011, Barcelos et al. 2013). Only six records (11\%) indicated the stage of regeneration of the forest in which the study occurred (Richard et al. 1995, Fragoso \& Huffman 2000, Richard \& Juliá 2001, Gayot et al. 2004, Hibert et al. 2011, Barcelos et al. 2013) (Table 1). This paucity of data makes it difficult to perform a rigorous assessment of the role of secondary forests in the foraging pattern of large mammals (Dunn 2004). Information about the conservation status of the study areas was also limited. Only 12 records (22\%) mentioned the type and degree of anthropogenic disturbance at the study site (Table 1). Agriculture, livestock production and logging were the most common anthropogenic activities in the study areas.

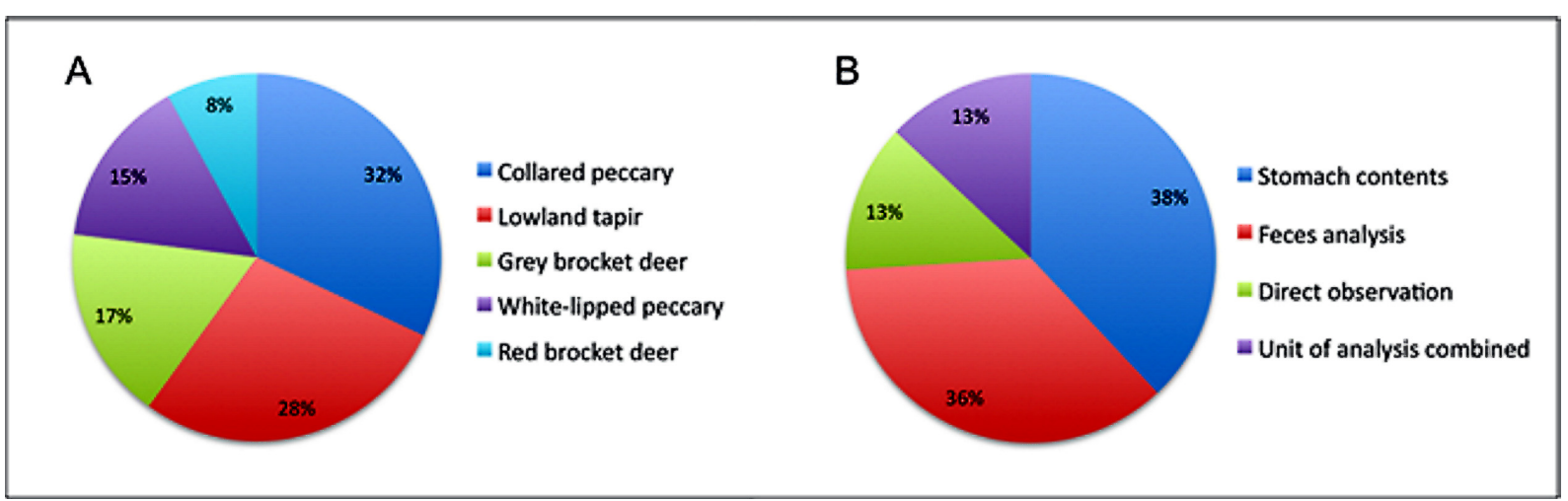

Figure 1. Proportion of diet records for each ungulate analyzed in this review (A). Proportion of ungulate diet records that adopted each unit of analysis above listed (B). Data based on 53 ungulate diet records. 
Table 1. Number and proportion of ungulate diet records reporting basic information about study area and data collection procedures adopted (data based on 53 diet records).

\begin{tabular}{ll}
\hline \hline METHODOLOGICAL TOPICS & NUMBER OF DIET RECORDS (\%) \\
\hline \hline Duration of data collection reported & $35(66)$ \\
Size of the study area informed & $29(55)$ \\
Conservation status of the study area informed & $12(23)$ \\
Number of sampling sites used on the landscape informed & $9(17)$ \\
Stage of forest succession in the study area reported & $6(11)$ \\
Size of the effective sampling area* reported & $5(9)$ \\
Sampling sufficiency analysis presented & $5(9)$ \\
\hline \hline
\end{tabular}

* area where feces and stomachs were searched and foraging direct observations were performed

The time period of data collection was explicitly reported in 36 records $(68 \%)$ and ranged from three to 78 months (mean $=20.8$, median $=16$, standard deviation=16.3 months) (Table 1). Twenty records (38\%) used stomach contents as the unit of analysis, 19 $(36 \%)$ were based on fecal analyses, and seven (13\%) were based on direct observations. Combinations of various analyses were also used (Figure 1). The number of stomach content samples used in each study varied from five to 121 (mean=35, median=31, standard deviation=25.9 samples), and the number of fecal samples varied from 10 to 356 (mean $=117$, median $=104.5$, standard deviation $=91.3$ ). Of the 13 records that included direct observation as a sampling method, only one record reported the number of observation events used in the research (82 events) (Santos et al. 2005).

Only five diet records (about $9 \%$ of the total) addressed the issue of sampling sufficiency (Table 1), three studies for the lowland tapir, and two for both the grey brocket and the red brocket deer. Based on collectors'curve approach (plotting accumulated number of the species against sampling effort), the studies for the lowland tapir showed that 53 fecal samples (Hibert et al. 2011), 94 fecal samples (Barcelos et al. 2013), and even 135 fecal samples (Tobler et al.2010) could not be adequate to estimate the diet richness of this ungulate. Regarding deer species, Gayot et al. (2004) observed that 28 stomachs of the red brocket and that 34 stomachs of the grey brocket were both insufficient to assess suitably these ungulates diet (in terms of plant species). Conversely, Branan et al. (1985) suggested that 57 red brocket deer's stomachs could be adequate to this aim. No record diet for the white-lipped peccary and the collared peccary reported such methodological aspect of the research.
In summary, the main limitations of these studies were related to a lack of information about the number of sampling sites and the size of the sampling areas. This criticism does not apply to the studies that used stomach content analyses because in these cases, the samples were obtained from local hunters. However, studies that use analyses of fecal samples and direct observation methods can easily include basic information about sampling design and procedures.

\section{Methods of Diet Analysis}

Diet records for the lowland tapir showed predominance of fecal sample analyses (used alone or in combination with other methods in $82 \%$ of the records), with only a few examples of stomach content analyses (18\%) and direct observation of foraging $(18 \%)$. The lowland tapir tends to defecate repeatedly in specific locations in the forest (Fragoso 1997, Fragoso \& Huffman 2000, Hibert et al. 2011) and defecates in large amounts, allowing for feces to be easily obtained over prolonged periods. The large quantity of seeds in the feces and the high degree of preservation of the seeds after defecation also makes fecal sample collection the preferred sampling method. On the other hand, the lowland tapir is usually found at low population densities (Eisenberg \& Redford 1999). As a result, this mammal is less common than other species in the diets of local hunting communities, making stomach content samples difficult to obtain, and direct observation nearly impossible in the natural environment.

Diet studies for the collared and white-lipped peccaries show that researchers used preferentially stomach content analysis (used in 52\% of the records), followed by fecal analysis (40\%) and direct observation of foraging (40\%). The few records for the diet of the red brocket deer were based on stomach 
content analyses (Branan et al. 1985, Bisbal 1994, Bodmer 1991b, Gayot et al. 2004). These studies were conducted in rural communities in the Amazon where the species is often abundant and widely hunted, thereby facilitating access to butchered stomachs for analysis (Branan et al. 1985, Bisbal 1994, Bodmer 1991b, Gayot et al. 2004). Studies of the grey brocket deer mostly relied on stomach content analyses (used in 55\% of the records) (Stallings 1984, Branan et al. 1985, Bodmer 1991b, Bisbal 1994, Gayot et al. 2004), followed by fecal analyses (33\%) (Kufner et al. 2008, Pinder 2004, Serbent et al. 2011) and direct observation (22\%) (Richard et al. 1995, Richard \& Juliá 2001).

Overall, for the five ungulates, the analysis of fecal or stomach samples was the most common type of analysis (Figure 1). Fecal samples are generally easier to obtain, but stomach samples are easier to obtain in area where there are indigenous communities hunting the animals. Direct observation of foraging was shown to be unique because it allows for the identification of diet items that are not preserved in stomach contents or in feces. However, direct observation is only feasible in specific contexts, such as with semi-captive animals or in open environments where the animals can be observed at a distance.

It is worth highlighting an innovative use of mixed methods that included (1) direct foraging observation to identify the plants consumed by lowland tapirs; (2) a molecular analysis of fecal samples to identify plant fragments and (3) recording ecological knowledge of local population. This mixed methodology was applied by Hibert et al. (2011) in a study of the diet of the lowland tapir in French Guiana in an area with indigenous Wayãpi communities. These are highly complementary approaches, and molecular analysis of animal diets is a technique with a large amount of potential that has yet to be explored. In addition, Prado et al. (2013) also have argued toward the efficacy of an ethnoecological approach in ungulate diet studies.

\section{Diet of the Lowland Tapir}

The lowland tapir was shown to consume fruits, leaves, fibers, twigs, stems and flowers. In the Peruvian Amazon, fruits, leaves and fibers were found in similar proportions in the tapir's diet (Bodmer 1990, 1991a). In French Guiana, samples of tapir diets contained a larger proportion of fibrous material (Henry 2000), and the tapirs in this region consumed a greater diversity of leaves (measured by the number of identified species) than fruits (Hibert et al. 2011).

In a mosaic of Semideciduous Forest and Igapó Forest in Bolivia, an analysis of the tapir's diet found a predominance of leaves, followed by fibers and fruits (Herrera et al. 1999). Higher consumption of fibers than other foods was observed in southeastern Brazil (Talamoni \& Assis 2009). For feces found in sandbank vegetation on the Brazilian coast, leaves were present in almost $50 \%$ of the feces, and stem fragments were present in 40\% (Santos et al. 2005). The same study showed that the tapirs fed primarily on herbaceous and shrub species that were common in the early stages of forest regeneration.

In general, a larger portion of the plant biomass is available to fauna during early stages of succession compared to more advanced stages (Bowen et al. 2007). Indeed, T. terrestris and T. bairdii have often been observed foraging in patches of secondary vegetation (Naranjo 1995, Salas \& Fuller 1996, Foerster \& Vaughan 2002, Tobler 2002). The same pattern has been observed in other animal groups (Bowen et al. 2007), reinforcing the hypothesis that tropical secondary forests may benefit part of the fauna (Wright \& Muller-Landau 2006).

The tapir's diet comprises mainly vegetative plant parts. All of the studies except Bodmer (1990, 1991a) found that leaves and fibers were the most commonly consumed items, with fruits and seeds playing a smaller role, regardless of biome, habitat type or sampling method. In fact, non-ruminant large herbivores such as the tapir can efficiently digest lowquality food, especially plant fibers (Demment \& Van Soest, 1985). The feeding strategy of these animals is to forage large quantities of food with low nutritional value, which is usually abundant, rather than a smaller quantity of food with higher nutritional value (Bodmer 1990) (e.g., fruit pulp and seeds), which require a greater energy investment during foraging.

While fibers were the predominant plant part in most tapir diets, in the Peruvian Amazon these ungulates were found to consume large proportions of fruits from monotypic clumps of the palm Mauritia flexuosa (Bodmer 1990). Given the considerably reduced foraging costs in this context, the benefits of frugivory seem to have been maximized, resulting in greater fruit intake by the tapirs (Bodmer 1990). The palm clumps, which are typically associated with historic and prehistoric processes of human occupation 
(Balée 1987, 1993; Politis 2001), may play an important role in the foraging dynamics of many animal species and are an interesting topic of research for combined ecological, anthropological and archaeological studies.

\section{Diets of the Red and Grey Brocket Deer}

The small number of studies of the red brocket deer showed that this species is predominantly frugivorous in the Amazon, although its diet also includes flowers, fungi and arthropods, which are often found in the samples in small proportions (Bodmer 1991a, Bisbal 1994, Gayot et al. 2004). The diet of the grey brocket deer includes fruits, leaves, fibers, flowers, roots, bark, shoots, stalks, twigs, minerals, fungi and animals. In the Amazon, fruits represented between 70 and 90 of the grey brocket deer's diet (Bodmer 1991a, Gayot et al. 2004), based on analyses of stomach content. However, a fecal analysis in the Pantanal (Brazil) showed that $90 \%$ of the species' diet was composed of leaves (Pinder 2004). Although the differences in the results of these studies could be attributed to differences in methods (namely, differences between stomach content and fecal analyses), it is also possible that this species is more frugivorous or more folivorous in different contexts. Further investigation is required to answer this question.

In the Chaco region of Argentina, tree and shrub elements dominated the diet of the grey brocket deer (Kufner et al. 2008). A similar pattern, but with increased importance of succulent species, was observed in the same region during a period of intense water stress (Serbent et al. 2011). In the phytogeographic province of Loa Yungas (Argentina), the diet of this species consisted of easily digestible and energy-rich food, including fruits, seeds, young leaves, shoots and flowers. Other elements were found in the diet during the period when the most nutritious items were scarce (Richard \& Juliá 2001).

In the same study, the grey brocket deer was also observed feeding on ticks from the species Haemaphysalis kohlsi (Ixodida, Ixodidae), which were found on other deer and a tapir, and was also observed feeding on an unidentified lepidopteran (Richard \& Juliá 2001). Earthy substances (geophagia), bird bones (osteophagia) and animal excrement (coprophagia) were also observed to be food items, in addition to salt and tiles from an old building site. The ingestion of minerals in general may be related to the processing of toxic secondary plant compounds. The fact that bones were observed in the stomach contents of a pregnant female and that eating earthy substances is more common among females has led other authors to hypothesize that there is an association between the consumption of minerals, such as calcium, and the specific nutritional requirements of pregnancy (Richard \& Juliá 2001). This type of information could only have been obtained using direct observation of foraging. Therefore, the use of this method is recommended for future studies, even though it is known to be difficult to implement in situ.

It is important mentioning that Richard and Juliá (2001) performed their observations in a semi-captive environment, which may be an alternative to in situ observations in natural habitat. Their study was performed in a fenced area of $\sim 20$ ha, belonging to a protected area of $\sim 200$ ha. The area consisted of pastures, shrub and secondary forest habitats, and the authors found out that the grey brocket deer consumed manly young leaves, fruit and flowers, comprising 73 botanical species in total. However, Richard and Juliá (2001) did not address how this semi-captive context could or not affect the density and healthy of this ungulate in the area. Therefore, it was not assessed the potential influence of this specific environmental context on the foraging habits of the grey brocket deer observed by the authors.

\section{Diet of the Collared Peccary}

Of the diet records for the collared peccary, 13 (76\%) addressed the relative importance of different items in the diet. In the Arizona desert, fibers represented $96 \%$ of the total volume of stomach samples, and the consumption of roots was considered common. The ingestion of vegetative parts of herbaceous species was significant during periods of low availability of other resources (Eddy 1961). A seasonal pattern was observed in Texas (USA), with greater consumption of herbaceous species in autumn, cacti in spring, herbaceous species and grasses in winter and herbaceous species and cacti in summer (Ilse 1995). The cactus Opuntia engelmannii was especially important in the collared peccary's diet, both in the desert region of Arizona and the arid regions of southern Texas (USA), accounting for 80 to $95 \%$ of the species' diet in those regions (Neal 1959, Eddy 1961, Everitt et al. 1981). 
A greater proportion of roots (47.9\%) and leaves $(41.2 \%)$ were recorded in the collared peccary's diet in Mexico (Martínez-Romero \& Mandujano 1995). Roots were also the primary item in the collared peccary's diet in Costa Rica (McCoy et al. 1990, Martínez-Romero \& Mandujano 1995). In summary, the diet of the collared peccary was found to be composed mainly of leaves and roots in North and Central America, regardless of the methods used. In contrast, studies from South America showed that this species was predominantly frugivorous in this region. These findings were based on the three methods used for diet analysis and represented a wide geographical gradient, ranging from northern South America to southeastern Brazil (Bodmer 1991a, Barreto et al. 1997, Salazar 2007, Keuroghlian \& Eaton 2008, 2009; Desbiez et al. 2009).

Collared peccaries in Bolivia were observed ingesting ticks found on other individuals of their group. These animals also consumed bird feathers (species from Tinamidae and Caprimulgidae), which is most likely due to the carcasivorous habit of this species (Salazar, 2007) and deserves further investigation. The consumption of an infant collared peccary by an adult was also observed (Salazar, 2007). Another study, carried out in Venezuela, showed a strong association between groups of collared peccaries and wedge-capped capuchins (Cebus olivaceus). The primates were present in 39 of the 86 observations of collared peccaries, who appeared to be following the primates and consuming the fruits discarded by them (Robinson \& Eisenberg 1985).

\section{Diet of the White-Lipped Peccary}

The review of studies of the white-lipped peccary indicated that its diet was composed of fruits, leaves, fibers, flowers, roots, stem, fungi, soil and animals. The literature also showed a consistent pattern of frugivory from Central America to southeastern Brazil (Bodmer 1991a, Barreto et al. 1997, Altrichter et al. 1999, 2000, 2001; Salazar 2007, Keuroghlian \& Eaton 2008, Desbiez et al. 2009), regardless of the methods employed.

The peccary was a seed predator for over $95 \%$ of the seeds in the Peruvian Amazon (Bodmer 1991b). In Costa Rica, the peccary was a predator of the seeds of 30 species, and a seed dispersal agent for only two species (Altrichter et al. 1999). In Costa Rica, earthworms were an important item in the peccary's diet, and this phenomenon may also occur in other habitats. However, the consumption of earthworms is rarely recorded because of the difficulty of observing earthworms in the stomach content and feces of ungulates (Altrichter et al. 2000). Again, the direct observation method is useful here in that it allows for recording the consumption of items that are absent from fecal and stomach content analyses.

In Bolivia, ticks and bird feathers (from the families Tinamidae and Caprimulgidae) were also found in the stomachs of white-lipped peccaries (Salazar 2007). Two opportunistic feeding habits related to the behavior of other mammals were recorded: (1) preferential foraging at the base of "objects" on the forest floor, such as trees, exposed roots, deadwood, vines and rocks, where rodents had deposited palm seeds (Astrocaryum sp.) (Kiltie 1981, Peruvian Amazon) and (2) consumption of palm seeds (Maximiliana maripa) directly from the feces of the lowland tapir (Fragoso 1999).

\section{Ecological Considerations of Species' Diets}

The predominantly herbivorous foraging habit of the lowland tapir, which is associated with a certain degree of selectivity (Salas \& Fuller 1996) and with foraging in patches of secondary vegetation (Naranjo 1995, Salas \& Fuller 1996, Foerster \& Vaughan 2002, Tobler 2002, Oliveira-Santos et al. 2010, Chalukian et al. 2013, García et al. 2012), plays an important role in the dynamics of forest regeneration because this species' foraging habit favors certain plant species over others. In terms of seed dispersal through frugivory, tapirs ingest seeds and defecate them whole (Bodmer 1991b, Barcelos et al. 2013). However, the feces are commonly deposited in flooded areas, which prevent the germination of many of the seeds (Bodmer 1991b, Fragoso \& Huffman 2000, Quiroga \& Roldan 2001).

In the Amazon, the tapir's movement over large distances and habit of defecating repeatedly in specific spots in the forest can result in the formation of clumps of M. maripa palm (Fragoso 1997). This observation suggests that the lowland tapir may also modify vegetation composition across landscapes at a scale of tens of kilometers. As one of the last Neotropical megafauna, the lowland tapir disperses seeds in a unique pattern, and its extinction would certainly eliminate this type of interaction with the vegetation, as no other native mammal would play the same 
ecological role in the Neotropics (Fragoso 1997, O'Farrill et al. 2013).

Both of the cervid species studied here were mostly frugivorous-granivorous in the Amazon. The brockets consume whole seeds, break down the hard parts of the seeds during rumination and process the chemical compounds in the seeds through pregastric fermentation in the rumen (Bodmer 1991b). The apparently greater dependency of the red brocket deer on fruits makes this species more vulnerable to habitat degradation and fragmentation because one of the consequences of these processes is decreased plant species richness, which decreases fruit and seed availability in fragmented habitat (Collinge 1996). On the other hand, the apparently folivorous habit of the grey brocket deer in the Pantanal (Brazil) (Pinder 2004) suggests that in addition to frugivory and granivory, this species may consume seedlings and vegetative parts of herbs, shrubs and young tree species, depending on its environment.

The diet of the collared peccary was composed mainly of leaves and roots in North and Central America (Neal 1959, Ilse 1995, Eddy 1961, McCoy et al. 1990, Martínez-Romero \& Mandujano 1995, Everitt et al. 1981) and of fruits and seeds in the southern portion of the continent (Bodmer 1991, Barreto et al. 1997, Salazar 2007, Keuroghlian \& Eaton 2008, Desbiez et al. 2009, Keuroghlian et al. 2009). It was also observed that seed predation by collared peccaries is more common than seed dispersal (Bodmer 1991b, Beck 2006). White-lipped peccaries also play a limited role in seed dispersal (Bodmer 1991b, Altrichter et al. 1999, Beck 2006). This species forms large groups of hundreds of individuals that forage over vast areas, depend on a large variety of habitats, and follow temporal variations in resource availability to meet their needs during the different times of the year (Fragoso 1998, 1999, Keuroghlian et al. 2009, Reyna-Hurtado et al. 2012). This foraging pattern makes this species highly vulnerable to impacts from anthropogenic activities that occur at the same landscape scale as the foraging scale of the animals (Fragoso 1999), such as extensive agriculture and livestock production. Indeed, reports of population decline and local extinction of this species in areas of agricultural use are not uncommon (Peres 1996a, 2001; Cullen et al. 2000, Azevedo \& Conforti 2008, Keuroghlian et al. 2013).

\section{Discrete Foraging Patterns of Ungulates}

The studies reviewed here also described how foraging strategies result in interactions between mammals, as in the case of the white-lipped peccary, whose foraging pattern following the distribution of seeds (Astrocaryum sp.) deposited by rodents (Kiltie 1981) and who also consumed seeds directly from the feces of the lowland tapir (Fragoso 1999). The collared peccary was found to display similar behavior by following groups of wedge-capped capuchins, and it was suggested that the peccaries may have eaten of the fruits discarded by these animals (Robinson \& Eisenberg 1985). Similarly, the grey brocket deer has been observed feeding on ticks on a lowland tapir (Richard \& Juliá 2001).

These observations of ungulate foraging have revealed interactions among mammals that are otherwise difficult to observe. In fact, these types of interactions are considered to be rare because of a lack of observations of similar behaviors. However, a comprehensive literature review shows that opportunistic interactions such as the one observed between collared peccaries and wedge-capped capuchins may be more common than has been previously thought. Similar types of foraging interactions have been observed between ungulates and primates in India and Ceylon (Robinson \& Eisenberg 1985), between birds and primates (Zhang \& Wang 2000, Kuniy et al. 2003, Boinski \& Scott 1988, Heymann 1992), between birds and coatis (Nasua nasua) (Beisiegel 2007), between birds and other ungulates (Marcus 1985, Peres 1996b), between primates and coatis, and between primates and tayras (Eira barbara) (Haugaasen \& Peres 2008).

Geophagous, osteophagous (bird bones) and coprophagous habits were also recorded for the grey brocket deer (Richard \& Juliá 2001), and bird feathers were found in the stomachs of collared and white-lipped peccaries (Salazar 2007). Interviews with rural residents also provided evidence of feathers in the digestive tract of cervids in Atlantic Forest (south-eastern Brazil) (Vogliotti 2003, Prado et al. 2013). These unusual foraging habits, though little studied, may be important in the diet of some ungulates. Because these strategies likely address physiological needs that are not yet well understood, manipulated experiments examining the nutritional physiology of these species in captivity, in addition to direct observations of foraging in situ, would be valuable methods for future research. 


\section{Final Considerations}

A list of plant species and families (see supplementary file 1) was created to facilitate access for researchers and conservation practitioners to information about the plants that are currently considered the main food sources for the ungulates in this study. The review allowed for an assessment of current knowledge about the diet of these species in the different environments where they are found, including the identification of little-understood foraging patterns that require additional studies. This review also reveals important limitations regarding adoption and description of data collection procedures used in these studies. About $30 \%$ of the studies analyzed do not report the duration of the data collection and almost $50 \%$ do not inform the size of the study area. In addition, most of the studies do not present any information about conservation status in the study area. Besides, less than $10 \%$ of them report the size of the effective sampling area or address the issue of temporal or spatial sampling sufficiency (Table 1).

In animal diet studies, information about the relationship of the sampling effort (i.e. number and size of sampling sites) to different elements on the landscape can be useful, especially in highly heterogeneous environments where the quantity and spatial arrangement of sampling sites may have significant effects on the diet composition record. Indeed, this kind of information can support key decisions and practices concerning the conservation of ungulate species. In addition, diet studies have shown great variation in terms of the number of samples and the time period for sampling, which compromise any further effort to compare diets within and between species. There was also a lack of studies from Neotropical environments of great concern for conservation, such as the Brazilian Caatinga and Cerrado. Finally, in order to improve our ecological knowledge about these ungulates, and make its conservation programs more effective, future diet studies ought to overcome the set of current methodological limitations herein discussed.

ACKNOWLEDGMENTS. This study is part of the author's $\mathrm{PhD}$ research, which was funded by the São Paulo Research Foundation (Fundação de Amparo à Pesquisa do Estado de São Paulo; process 2008/509513). Fausto Oliveira Gomes and Paula Giroldo helped with their assistance in organizing the data compilation, and Vania Quibao Pretti checked and corrected the taxonomic nomenclature of plants. The author also expresses his gratitude to Rui Murrieta and Cristina Adams for their valuable comments on the manuscript.

\section{REFERENCES}

Altrichter, M., J. Sáenz, and E. Carrilo. 1999. Chanchos Cariclancos (Tayassu pecari) como depredadores y dispersores de semillas en el Parque Nacional Corcovado, Costa Rica. Brenesia 52:53-59.

Altrichter, M., J. C. Sáenz,_E. Carrillo, and T. K. Fuller. 2000. Dieta estacional del Tayassu pecari (Artiodactyla: Tayassuidae) en el Parque Nacional Corcovado, Costa Rica. Revista de Biología Tropical 48:689-702.

Altrichter, M., J. C. Sáenz, E. Carrillo, and T. K. Fuller. 2001. White-lipped peccary (Tayassu pecari,

Artiodactyla: Tayassuidae) diet and fruit availability in a Costa Rican rain forest. Revista de Biología Tropical 49:1183-1192. Altrichter, M., and R. Almeida. 2002. Exploitation of white-lipped peccaries Tayassu pecari (Artiodactyla: Tayassuidae) on the Osa Peninsula, Costa Rica. Oryx 36:126-132.

Asquith, N. M., S. J. Wright, and M. J. Clauss. 1997. Does Mammal Community Composition Control Recruitment in Neotropical Horests? Evidence From Panama. Ecology 78:941-946.

Augustine, D. J., and L. E. Frelich. 1998. Effects of whitetailed deer on populations of an understory forb in fragmented deciduous forests. Conservation Biology 12:995-1004.

Azevedo, F. C. C., and A. C. Conforti. 2008. Decline of peccaries in a protected subtropical forest of Brazil: toward conservation issues. Mammalia 72:82-88.

Balée, W. 1987. Cultural Forests of the Amazon. Garden 11:12-32.

Balée W. 1993. Indigenous transformation of Amazonian forests: an example from Maranhão, Brazil. Homme. 33: 231-54.

Barcelos, A. R., P. E. D. Bobrowiec, T. M. Sanaiotti, and R. Gribel. 2013. Seed germination from lowland tapir (Tapirus terrestris) fecal samples collected during the dry season in the Northern Brazilian Amazon. Integrative zoology 8(1):63-73.

Barreto, G. R., O. E. Hernandez, and J. Ojasti. 1997. Diet of peccaries (Tayassu tajacu and T. pecari) in dry forest of Venezuela. Wildlife Conservation 241:279-284.

Beck, H. 2006. A Review of Peccary-Palm Interactions and Their Ecological Ramifications Across the Neotropics. Journal of Mammalogy 87:519-530.

Beisiegel, B. M. 2007. Foraging Association between Coatis (Nasua nasua) and Birds of the Atlantic Forest, Brazil. Biotropica 39:283-285.

Bisbal. F. J. E. 1994. Biologia poblacional del venado matacán (Mazama spp.) (Artiodactyla: Cervidae) em Venezuela. Revista de Biología Tropical 42:305-313.

Bodmer, R. E. 1990. Fruit patch size and frugivory in the lowland tapir (Tapirus terrestris). Journal of Zoology 222:121-128.

Bodmer, R. E. 1991a. Influence of digestive morphology on resource partitioning in Amazonian ungulates. Oecologia $85: 361-365$

Bodmer, R. E. 1991b. Strategies of Seed Dispersal and Seed Predation in Amazoniam Ungulates. Biotropica 23: 255-261.

Bodmer, R.E., T.G. Fang, L. Moya, and R. Gill. 1994. Managing Wildlife to conserve Amazonian forest: population biology and economic considerations of game hunting. Biological 
Conservation 69:29-35.

Boinski, S., and P. E. Scott. 1988. Association of birds with monkeys in Costa Rica. Biotropica 20:136-143.

Bowen, M. E., C. A. Mc.alpine, A. P. N. House, and G. C. Smith. 2007. Regrowth forests in abandoned agricultural land: a review of their values for recovering forest fauna. Biological Conservation 140:273-296.

Branan, W. V., M. C. M. Werkhoven, and R. L. Marchinton. 1985. Food Habits of Brocket and White-Tailed Deer in Suriname. The Journal of Wildlife Management 49:972-976.

Carrillo, E., J. C. Saenz, and T. K. Fuller. 2002. Movements and activities of white-lipped peccaries in Corcovado National Park, Costa Rica. Biological Conservation 108:317-324.

Chalukian, S. C., M. S. De Bustos, and R. L. Lizárraga. 2013. Diet of lowland tapir (Tapirus terrestris) in El Rey National Park, Salta, Argentina. Integrative Zoology 8(1):48-56.

Collinge, S. K. 1996. Ecological Consequences of Habitat Fragmentation: Implications for Landscape Architecture and Planning. Landscape and Urban Planning 36:59-77.

Cullen Jr., L., R. E. Bodmer, and C. Valladares-Padua. 2000. Effects of hunting in habitat fragments of the Atlantic forests, Brazil. Biological Conservation 95:49-56.

Demment, M. W., and P. J. Van Soest. 1985. A Nutritional Explanation for Body-Size Patterns of Ruminant and NonRumant Herbivores. American Naturalist 125:641-672.

Desbiez, A. L. J., S. A. Santos, A. Keuroghlian, and R. E. Bodmer. 2009. Niche Partitioning Among White-Lipped Peccaries (Tayassu pecari), Collared Peccaries (Pecari tajacu), and Feral Pigs (Sus Scrofa). Journal of Mammalogy 90:119-128.

Dewalt, S. J., S. K. Maliakal, and J. S. Denslow. 2003. Changes in vegetation structure and composition along a tropical forest chronosequence: Implications for wildlife. Forest Ecology and Management 182:139-151.

Dunn, R. R. 2004. Recovery of faunal communities during tropical forest regeneration. Conservation Biology 18:302-309.

Eddy, T. A. 1961. Foods and Feeding Patterns of the Collared Peccary in Southern Arizona. The The Journal of Wildlife Management 25:248-257.

Eisenberg, J. F., And K.H. Redford. 1999. Mammals of the neotropics: Ecuador, Peru, Bolivia, and Brazil, vol.3. University of Chicago Press, Chicago, Illinois, USA.

Everitt, J. H., Gonzalez, C. L., Alaniz, M. A., and Latigo, G. V. 1981. Food Habits of the Collared Peccary on South Texas Rangelands. Journal of Range Management 34:141-144.

Foerster, C. R., and C. Vaughan. 2002. Home range, habitat use, and activity of Baird's tapir in Costa Rica. Biotropica 34:423-437.

Fragoso, J. M. V. 1997. Tapir-Generated Seed Shadows: Scale-Dependent Patchiness in the Amazon Rain Forest. Journal of Ecology 85:519-529

Fragoso, J. M. V. 1998. Home range and movement patterns of white-lipped peccary (Tayassu pecari) herds in the northern Brazilian Amazon. Biotropica 30:458-469.

Fragoso, J. M. V. 1999. Perception of scale and resource partitioning by peccaries: behavioral causes and ecological implications. Journal of Mammalogy 80:993-1003.

Fragoso, J. M. V., and J. M. Huffman. 2000. Seeddispersal and seedling recruitment patterns by the last Neotropical megafaunal element in Amazonia, the tapir. Journal of Tropical Ecology 16:369-385.

García, M. J., E. P. Medici, E. J. Naranjo, W. Novarino, and R. S. Leonardo. 2012. Distribution, habitat and adaptability of the genus Tapirus. Integrative Zoology 7(4):346-55.

Gardner, T. A., J. Barlow, L. W. Parry, and C. A. Peres. 2007. Predicting the uncertain future of tropical forest species in a data vacuum. Biotropica 39:25-30.

Gayot, M., O. Henry, G. Dubost, and D. Sabatier. 2004. Comparative diet of the two forest cervids of the genus Mazama in French Guiana. Journal of Tropical Ecology 20:31-43.

Haugaasen, T. and C. A. Peres. 2008. Associations between primates and other mammals in a central Amazonian forest landscape. Primates 49: 219-222.

Henry, O., F. Feer, and D. Sabatier. 2000. Diet of the Lowland Tapir (Tapirus terrestris) in French Guiana. Biotropica 32:364-368.

Heymann, E. W. 1992. Associations of tamarins (Saguinus mystax and Saguinus fuscicollis) and double-toothed kites (Harpagus bidentatus) in Peruvian Amazonia. Folia Primatologica 59:51-55.

Herrera, J. C., A. B. Taber, R. B. Wallace, and R. L. E. Painter. 1999. Lowland tapir (Tapirus terrestris) behavioural ecology in the southern Amazonian tropical forest. Vida Silvestre Neotropical 18:31-37.

Hibert, F., D. Sabatier, J. Andrivot, C. Scotti-saintagne, S. Gonzalez, and H. Caron. 2011. Botany, Genetics and Ethnobotany/: A Crossed Investigation on the Elusive Tapir's Diet in French Guiana. PLoS ONE 6(10): e25850.doi:10.1371/ journal.pone. 0025850

Howe, H. F., and J. Smallwood. 1982. Ecology of seed dispersal. Annual Review of Ecology and Systematics 13:201-228.

Ilse, L. M., and E. C. Hellgren. 1995. Resource Partitioning in Sympatric Populations of Collared Peccaries and Feral Hogs in Southern Texas. Journal of Mammalogy 76:784-799.

Jácomo, A. T. A., M. M. Furtado, C. K. Kashivakura, J. Marinho-Filho, R. Sollmann, N. M. Tôrres, and L. Silveira. 2013. White-lipped peccary home-range size in a protected area and farmland in the central Brazilian grasslands. Journal of Mammalogy 94(1):137-145.

Judas, J., and O. Henry. 1999. Seasonal variation of home range of collared peccaries in tropical rain forests of French Guiana. The Journal of Wildlife Management 63:546-552.

Keuroghlian, A., D. P. Eaton, and W. S. Longland. 2004. Area use by white-lipped and collared peccaries (Tayassu pecari and Tayassu tajacu) in a tropical forest fragment. Biological Conservation 120:411-425.

Keuroghlian, A., and D. P. Eaton. 2008. Importance of rare habitats and riparian zones in a tropical forest fragment: preferential use by Tayassu pecari, a wide-ranging frugivore. Journal of Zoology 275:283-293.

Keuroghlian, A., D. P. Eaton, and A. L. J. Desbiez. 2009. The response of a landscape species, white-lipped peccaries, to seasonal resource fluctuations in a tropical wetland, the Brazilian pantanal. International Journal of Biodiversity and Conservation 1:87-97.

Keuroghlian, A., A. Desbiez, R. Reyna-Hurtado, M. Altrichter, H. Beck, A. Taber, and J. M. V. Fragoso. 2013. Tayassu pecari. In: IUCN 2013. IUCN Red List of Threatened Species. Version 2013.1. <www.iucnredlist.org>. Downloaded on 15 July 2013.

Kiltie, R. A. 1981. Distribution of Palm Fruits on a Rain Forest Floor: Why White-lipped Peccaries Forage near Objects. Biotropica 13:141-145.

Kiltie, R. A., and J. Terborgh. 1983. Observations on the behavior of rain forest peccaries in Peru: why do white-lipped peccaries form herds? Zeitschrift für Tierpsychologie 62:214-255. 
Kufner, M. B., L. Sepúlveda, G. Gavier, L. Madoery, and L. Giraudo, L. 2008. Is the native deer Mazama gouazoubira threatened by competition for food with the exotic hare Lepus europaeus in the degraded Chaco in

Córdoba, Argentina? Journal of Arid Environments 72:2159-2167.

Kuniy, A. A., M. M. De Morais Jr., and E. P. C. Gomes. 2003. Associação do arapaçu-verde (Sittasomus griseicapillus, Vieillot, 1818) com o mico leão dourado (Leontopithecus rosalia, Linnaeus, 1766), Reserva Biológica União, Rio das Ostras, Brasil. Acta Biologica Leopoldensia 25:261-264.

Maffei, L., and A. B. Taber. 2003. Area de acción de Mazama americana (Cervidae) em um bosque seco de Bolivia. Ecologia em Bolívia 38:179-180.

Marcus, M. I. 1985. Feeding associations between capybaras and jacanas: A case of interspecific grooming and possibly mutualism. Ibis 127:240-243.

Martínez-Romero, L. E., and S. Manfujano. 1995. Habitos alimentarios del Pecari de Collar (Pecari tajacu) em um bosque tropical caducifolio de Jalisco, Mexico. Acta Zoológica Mexicana 64:1-20.

McCoy, M. B., C. S. Vaughan, M. A. Rodrigues, and D. Kitchen. 1990. Seasonal movements, home range, activity and diet of collared peccaries (Tayassu tajacu) in Costa Rican dry forest. Vida Silvestre Neotropical 2:6-20.

McNaughton, S.J., R. W. Ruess, and S. W. Seagle. 1988. Large mammals and process dynamics in African ecosystems. BioScience 38:794-801.

Ministério do Meio Ambiente (MMA). 2008. Livro vermelho fauna brasileira ameaçada de extinção. A. B. M. Machado, G. M. Drummond, A. P. Paglia (Ed.). Brasília, Distrito Federal, Brasil.

Naranjo, E. J. 1995. Abundancia y uso de habitat del tapir (Tapirus bairdii) en un bosque tropical húmedo de Costa Rica. Vida Silvestre Neotropical 4:20-31.

Neal, B. J. 1959. A Contribution on the Life History of the Collared Peccary in Arizona. The American Midland Naturalist 61:177-190.

O'Farrill, G., M. Galetti, and A. Campos-Arceiz, A. 2013. Frugivory and seed dispersal by tapirs: an insight on their ecological role. Integrative Zoology 8(1):4-17.

Oliveira-Santos, L. G. R., L. C. P. Machado-Filho, M. A. Tortato, and L. Brusius 2010. Influence of extrinsic variables on activity and habitat selection of lowland tapirs (Tapirus terrestris) in the coastal sand plain shrub, southern Brazil. Mammalian Biology - Zeitschrift fur Saugetierkunde 75:219-226.

Peres, C. A. 1996a. Population status of white-lipped Tayassu pecari and collared peccaries T. tajacu in hunted and unhunted Amazonian forests. Biological Conservation 77:115-123.

Peres, C. A. 1996b. Ungulate ectoparasite removal by Black Caracarás (Daptrius ater) and Pale-winged Trumpeters (Psophia leucoptera) in Amazonian forests. The Wilson Bulletin 108:170-175.

Peres, C. A. 2001. Synergistic effects of subsistence hunting and habitat fragmentation on Amazonian forest vertebrates. Conservation Biology 15:1490-1505.

Pinder, L. 2004. Niche partitioning among Gray Brocket Deer, Pampas Deer, and Catle in the Pantanal of Brazil. Pages 257-270 in K. M. Silvius, R. E. Bodmer, and J. M. V. Fragoso, editors. People in nature: wildlife conservation in South and Central America. Columbia University Press, New York, New York, USA.
Politis, G. 2001. Foragers of the Amazon: the last survivors or the first to succeed? Pages 26-49 in C. McEwan, C. Barreto, and E. G. Neves, editors. Unknown Amazon: Culture in Nature in Ancient Brazil. British Museum Press, London, United Kingdom.

Prado, H. M., R. S. S. Murrieta, C. Adams, and E. S. Brondizio. 2013. Complementary Viewpoints: Scientific and Local Knowledge of Ungulates in the Brazilian Atlantic Forest. Journal of Ethnobiology 33(2):180-202.

Prado, H. M., R. S. S. Murrieta, C. Adams, and E. S. Brondizio. 2014. Local and scientific knowledge for assessing the use of fallows and mature forest by large mammals in SE Brazil: identifying singularities in folkecology. Journal of Ethnobiology and Ethnomedicine 10:7. http://www.ethnobiomed.com/content/10/1/7

Quiroga-Castro, V. D., and A. I. Róldan. 2001. A Fate of Attalea Phalerata (Palmae) Seeds dispersed to a Tapir Latrine. Biotropica 33:472-477.

Reyna-Hurtado, R., C. A. Chapman, S. Calme, and E. J. Pedersen. 2012. Searching in heterogeneous and limiting environments: foraging strategies of white-lipped peccaries (Tayassu pecari). Journal of Mammalogy 93(1):124-133.

Richard, E., J. P. Juliá, and P. Aceñolaza. 1995. Hábitos frugívoros de la corzuela parda (Mazama gouazoubira, Fischer, 1814) (Mammalia - Cervidae), en un ambiente secundario de Yungas. Doñana Acta Vertebrata 22:19-28.

Richard, E., and J. P. Juliá. 2001. Dieta de Mazama Gouazoubira (Mammali, Cervidae) em um ambiente secundário de Yungas, Argentina. Iheringia. Série Zoologia 90:147-156.

Robinson, A. J. G., and Eisenberg, J. F. 1985. Group Size and Foraging Habits of the Collared Peccary Tayassu tajacu. Journal of Mammalogy 66:153-155.

Robinson, J. G., and K. H. Redford. 1986. Intrinsic rate of natural increase in neotropical forest mammals: Relationship to phylogeny and diet. Oecologia 68:516-20.

Robinson J., and E. Bennett. 2000. Hunting for sustainability in Tropical Forest. Columbia University Press, New York, New York, USA.

Salas, L. A., and T. K. Fuller. 1996. Diet of the lowland tapir (Tapirus terrestris) in the Tabaro River valley, southern Venezuela. Canadian Journal of Zoology 74:1444-1451.

Salazar, R. S. M. 2007. Dieta de los chanchos de monte: Taitetu (Tayassu tajacu ) y Tropero (Tayassu pecari) en el territorio indigena Siriono, Beni, Bolivia. Revista Boliviana de Ecología y Conservación Ambiental 21:43-56.

Santos, L. G. R. O., L. C. P. Machado-Filho, M. A. Tortato, D. B. Falkemberg, and M. J. Hötzel. 2005. Diet of Tapirs (Tapirus terrestris) Introduced in a Salt Marsh Area of the Baixada do Massiambu, State Park of the Serra do Tabuleiro - Santa Catarina, South of Brazil. Tapir Conservation 14/2: 22-27.

Serbent, M. P., M. E. Periago, and G. C. Leynaud. 2011. Mazama gouazoubira (Cervidae) diet during the dry season in the arid Chaco of Córdoba (Argentina). Journal of Arid Environments 75:87-90.

Stallings, J. R. 1984. Notes on Feeding Habits of Mazama Gouazoubira in the Chaco Boreal of Paraguay. Biotropica 16:155-157.

Stoner, E. K., K. Vulinek, S. J. Wright, and C. A. Peres. 2007. Hunting and Plant Community Dynamic in Tropical Forests: A Synthesis and Future Directions. Biotropica 39:385-392.

Taber, A. B., C. P. Doncaster, N. N. Neris, and F. Colman. 1994. Ranging behaviour and activity patterns of two sympatric peccaries, Catagonus wagneri and Tayassu tajacu, in Paraguayan 
Chaco. Mammalia 1:61-71.

Talamoni, S. A., and M. A. C. Assis. 2009. Feeding habit of the Brazilian tapir, Tapirus terrestris (Perissodactyla: Tapiridae) in a vegetation transition zone in south-eastern Brazil. Zoologia 26:251-254.

Terborgh, J., and S. J. Wright. 1994. Effects of mammalian herbivores on seedling recruitment and survivorship in two neotropical forests. Ecology 75:1829-1833.

Tobler, M. 2002. Habitat use and diet of Baird's tapirs (Tapirus bairdii) in a Montane Cloud Forest of the Cordillera de Talamanca, Costa Rica. Biotropica 34:468-474.

Tobler, M. W., S. E. Carrilo-Percastegui, and P. George. 2009. Habitat use, activity patterns and use of mineral licks by five species of ungulate in south-eastern Peru. Journal of Tropical Ecology 25:261-270.
Tobler, M. W., J. P. Janovec, and F. Cornejo. 2010. Frugivory and Seed Dispersal by the Lowland Tapir Tapirus terrestris in the Peruvian Amazon. Biotropica 42:215-222.

Wright, S.J., and H. C. Muller-Landau. 2006. The uncertain future of tropical forest species. Biotropica 38(4): 443-445.

Vogliotti, A. 2003. História natural de Mazama bororo (Artiodactyla; Cervidae) através da etnozoologia, monitoramento fotográfico e rádio-telemetria. Dissertação de Mestrado, Escola Superior de Agricultura “Luis Queiroz”, Universidade de São Paulo, Piracicaba. http://www.teses.usp.br/teses/disponiveis/91/91131/tde29072004-161012/pt-br.php

Zhang, S., and L. Wang. 2000. Following of brown capuchin monkeys by white hawks in French Guiana. The Condor 102:198-201. 


\section{ANNEX 1}

Table 1. The most common ${ }^{a}$ plant taxa in the diets of five ungulates, listed in alphabetic order of botanical family.

\begin{tabular}{|c|c|c|c|c|c|c|c|}
\hline BOTANY FAMILY & BOTANY SPECIES & $\begin{array}{c}T . \\
\text { TERRESTRIS }\end{array}$ & $\begin{array}{c}M . \\
\text { AMERICANA }\end{array}$ & $\begin{array}{c}\text { M. } \\
\text { GOUAZOUBIRA }\end{array}$ & $\begin{array}{c}P . \\
T A J A C U\end{array}$ & $\begin{array}{c}T . \\
\text { PECARI }\end{array}$ & REFERENCES \\
\hline Agavaceae & Yucca treculeana & & & & $\mathrm{X}$ & & 24,26 \\
\hline Agavaceae & Agave palmeri & & & & $\mathrm{X}$ & & 28,29 \\
\hline Alismataceae & Echinodorus rostratus & & & & $\mathrm{X}$ & & 26 \\
\hline Anacardiaceae & Spondias mombin & $\mathrm{X}$ & & & & & 7 \\
\hline Anacardiaceae & Spondias sp. & & & & & $\mathrm{X}$ & 35 \\
\hline Anacardiaceae & Anacardium excelsum & & & & & $\mathrm{X}$ & 35 \\
\hline Anacardiaceae & Schinus sp. & & & $\mathrm{X}$ & & & 13 \\
\hline Annonaceae & * & $\mathrm{X}$ & & & & & 1 \\
\hline Apocynaceae & Pacouria guianensis & $\mathrm{X}$ & & & & & 7 \\
\hline Apocynaceae & Hancornia speciosa & & & & & $\mathrm{X}$ & 31 \\
\hline Araceae & $*$ & & & & & $\mathrm{X}$ & 35 \\
\hline Araliaceae & Schefflera decaphylla & & $\mathrm{X}$ & & & & 10 \\
\hline Arecaceae & Mauritia sp. & $\mathrm{X}$ & & & & & 2 \\
\hline Arecaceae & Syagrus romanzoffiana & $\mathrm{X}$ & & & $X$ & $\mathrm{X}$ & $3,6,21,32$ \\
\hline Arecaceae & Astrocaryum sp. & $\mathrm{X}$ & & & & & 7 \\
\hline Arecaceae & Mauritia flexuosa & $\mathrm{X}$ & & & & & 8,9 \\
\hline Arecaceae & Maximiliana maripa & $\mathrm{X}$ & & & & & 8 \\
\hline Arecaceae & Jessenia sp. & $\mathrm{X}$ & & & & & 9 \\
\hline Arecaceae & Scheelea sp. & $\mathrm{X}$ & & & & & 9 \\
\hline Arecaceae & Attalea phalerata & & & & $\mathrm{X}$ & $\mathrm{X}$ & $20,31,33$ \\
\hline Arecaceae & Euterpe edulis & & & & & $\mathrm{X}$ & 32 \\
\hline Arecaceae & Oenocarpus bacaba & & $\mathrm{X}$ & & & & 10 \\
\hline Balanophoraceae & Langsdorffia hypogaea & & & & $\mathrm{X}$ & & 20 \\
\hline Bombacaceae & Catostemma fragrans & & $X$ & & & & 10 \\
\hline Bombacaceae & Eriotheca sp. & & $\mathrm{X}$ & & & & 10 \\
\hline Bromeliaceae & Bromelia balansae & & & & $\mathrm{X}$ & $\mathrm{X}$ & 20,31 \\
\hline Cactaceae & $*$ & & & $\mathrm{X}$ & & & 12 \\
\hline Cactaceae & Cereus sp. & & & & $\mathrm{X}$ & & 20 \\
\hline Cactaceae & Opuntia lindheimeri & & & & $\mathrm{X}$ & & $24,25,26$ \\
\hline Cactaceae & Ferocactus wislizeni & & & & $X$ & & 27 \\
\hline Cactaceae & Carnegiea gigantea & & & & $\mathrm{X}$ & & 27 \\
\hline Cactaceae & Opuntia engelmannii & & & & $\mathrm{X}$ & & $27,28,30$ \\
\hline Cactaceae & Ferocactus wislizeni & & & & $\mathrm{X}$ & & 28 \\
\hline Caesalpiniaceae & Eperua falcata & & $\mathrm{X}$ & & & & 10 \\
\hline Caesalpiniaceae & Swartzia panacoco & & $\mathrm{x}$ & & & & 10 \\
\hline Cannabaceae & Celtis pallida & & & & $\mathrm{X}$ & & 28 \\
\hline Capparaceae & Capparis retusa & & & $\mathrm{X}$ & & & 19 \\
\hline Capparaceae & Capparis speciosa & & & $\mathrm{X}$ & & & 19 \\
\hline Caryophyllaceae & $*$ & & & $\mathrm{X}$ & & & 16 \\
\hline Cecropiaceae & Cecropia obtusa & & $X$ & & & & 10 \\
\hline Cecropiaceae & Cecropia sciadophylla & & $\mathrm{X}$ & & & & 10 \\
\hline Celastraceae & Maytenus spinosa & & & $\mathrm{X}$ & & & 12,13 \\
\hline Chrysobalanaceae & Licania operculipetala & & & & & $\mathrm{X}$ & 35 \\
\hline
\end{tabular}


Continued...

\begin{tabular}{|c|c|c|c|c|c|c|c|}
\hline BOTANY FAMILY & "BOTANY SPECIES & $\begin{array}{c}. \\
\text { TERRESTRIS }\end{array}$ & $\begin{array}{c}. \\
\text { AMERICANA }\end{array}$ & $\begin{array}{c}\text { M. } \\
\text { GOUAZOUBIRA }\end{array}$ & $\begin{array}{c}P . \\
T A J A C U \\
\end{array}$ & $\begin{array}{c}T . \\
\text { PECARI }\end{array}$ & REFERENCES \\
\hline Clusiaceae & Symphonia globulifera & & $\mathrm{X}$ & & & & 11 \\
\hline Commelinaceae & Commelina nudiflora & & & & & $\mathrm{X}$ & 31 \\
\hline Convolvulaceae & Ipomoea muricata & & & & $\mathrm{X}$ & & 29 \\
\hline Cyclanthaceae & Cyclanthus bipartitus & & $\mathrm{X}$ & & & & 10 \\
\hline Cyperaceae & Cyperus sp. & & & & $\mathrm{X}$ & & 29 \\
\hline Ericaceae & Arctostaphylos pungens & & & & $X$ & & 29 \\
\hline Fabaceae & $*$ & $\mathrm{X}$ & & & & & 1 \\
\hline Fabaceae & Dimorphandra mollis & $\mathrm{X}$ & & & & & 4 \\
\hline Fabaceae & $\begin{array}{l}\text { Enterolobium } \\
\text { schomburgkii }\end{array}$ & $\mathrm{X}$ & & & & & 8 \\
\hline Fabaceae & Swartzia sp. & & $\mathrm{X}$ & & & & 11 \\
\hline Fabaceae & Inga sp. & & & $\mathrm{X}$ & & $\mathrm{X}$ & 14,35 \\
\hline Fabaceae & Swartzia benthamianna & & & $\mathrm{X}$ & & & 18 \\
\hline Fabaceae & $\begin{array}{l}\text { Caesalpinia } \\
\text { paraguarensis }\end{array}$ & & & $\mathrm{X}$ & & & 19 \\
\hline Fabaceae & Mimosa sp. & & & & $\mathrm{X}$ & & 20 \\
\hline Fabaceae & Desmodium barbatum & & & & $\mathrm{X}$ & & 20 \\
\hline Fabaceae & Prosopis glandulosa & & & & $\mathrm{X}$ & & 24 \\
\hline Fabaceae & $\begin{array}{l}\text { Pithecellobium } \\
\text { flexicaule }\end{array}$ & & & & $\mathrm{X}$ & & 25 \\
\hline Fabaceae & $\begin{array}{l}\text { Cercidium } \\
\text { microphyllum }\end{array}$ & & & & $\mathrm{X}$ & & 27 \\
\hline Fabaceae & Prosopis juliflora & & & & $\mathrm{X}$ & & 27,28 \\
\hline Fabaceae & Acacia greggii & & & & $\mathrm{X}$ & & 28 \\
\hline Fabaceae & Mimosa obtusifolia & & & & & $\mathrm{X}$ & 31 \\
\hline Fabaceae & Pithecellobium saman & & & & & $\mathrm{X}$ & 36 \\
\hline Fabaceae & Cassia moschata & $\mathrm{X}$ & & & & & 8 \\
\hline Fagaceae & Quercus arizonica & & & & $X$ & & 28,29 \\
\hline Heliconiaceae & Heliconia $\mathrm{sp}$ & & & & & $\mathrm{X}$ & 35 \\
\hline Humiriaceae & Sacoglottis cydonioides & $\mathrm{X}$ & & & & & 7 \\
\hline Lauraceae & $*$ & & & & $X$ & $\mathrm{X}$ & 21,32 \\
\hline Lecythidaceae & Eschweilera sp. & & $\mathrm{X}$ & $\mathrm{X}$ & & & 10,14 \\
\hline Lecythidaceae & Lecythis persistens & & & $\mathrm{X}$ & & & 14 \\
\hline Malpighiaceae & Byrsonima orbignyana & & & & & $\mathrm{X}$ & 31 \\
\hline Malvaceae & Bombax spectabile & & $X$ & $X$ & & & 11,18 \\
\hline Malvaceae & Sida santamarensis & & & $\mathrm{X}$ & & & 15 \\
\hline Malvaceae & Sida rhombifolia & & & $\mathrm{X}$ & & & 16 \\
\hline Malvaceae & Sida sp. & & & & $\mathrm{X}$ & & 20 \\
\hline Malvaceae & Waltheria albicans & & & & $\mathrm{X}$ & & 20 \\
\hline Malvaceae & Guazuma ulmifolia & & & & $\mathrm{X}$ & & 23 \\
\hline Malvaceae & Quararibea asterolepis & & & & & $\mathrm{X}$ & 35 \\
\hline Melastomataceae & $*$ & $\mathrm{X}$ & & & & & 5 \\
\hline Melastomataceae & $\begin{array}{l}\text { Bellucia } \\
\text { grossularioides }\end{array}$ & & & $\mathrm{X}$ & & & 18 \\
\hline Meliaceae & Carapa guianensis & & $\mathrm{X}$ & & & & 10 \\
\hline Meliaceae & Guarea grandifolia & & $\mathrm{X}$ & & & & 10 \\
\hline Moraceae & Ficus sp. & $\mathrm{X}$ & $\mathrm{X}$ & $\mathrm{X}$ & & $\mathrm{X}$ & $2,10,14,35$ \\
\hline Moraceae & Perebea sp. & $\mathrm{X}$ & & & & & 2 \\
\hline
\end{tabular}


Conclusion.

\begin{tabular}{|c|c|c|c|c|c|c|c|}
\hline BOTANY FAMILY & BOTANY SPECIES & $\begin{array}{c}T . \\
\text { TERRESTRIS } \\
\end{array}$ & $\begin{array}{c}M . \\
\text { AMERICANA }\end{array}$ & $\begin{array}{c}M . \\
\text { GOUAZOUBIRA } \\
\end{array}$ & $\begin{array}{c}P . \\
\text { TAJACU } \\
\end{array}$ & $\begin{array}{c}T . \\
\text { PECARI } \\
\end{array}$ & REFERENCES \\
\hline Moraceae & Brosimum guianense & & & $\mathrm{X}$ & & & 14 \\
\hline Moraceae & Morus nigra & & & $\mathrm{X}$ & & & 16,17 \\
\hline Moraceae & Brosimum sp. & & & & & $\mathrm{X}$ & 35 \\
\hline Moraceae & Bagassa guianensis & & $\mathrm{X}$ & & & & 10,7 \\
\hline Myristicaceae & Virola kwatae & & $\mathrm{X}$ & & & & 10 \\
\hline Myristicaceae & Virola surinamensis & & $\mathrm{X}$ & $\mathrm{X}$ & & & 10,14 \\
\hline Myristicaceae & Virola michelii & & & $\mathrm{X}$ & & & 14 \\
\hline Myrtaceae & $*$ & $\mathrm{X}$ & & & $\mathrm{X}$ & $\mathrm{X}$ & $1,21,32$ \\
\hline Olacaceae & Ximenia americana & & & & $\mathrm{X}$ & $\mathrm{X}$ & 20,31 \\
\hline Onagraceae & Ludwigia multinervia & $\mathrm{X}$ & & & & & 5 \\
\hline Opiliaceae & Agonandra silvatica & & $\mathrm{X}$ & & & & 10 \\
\hline Phytolaccaceae & Rivina humilis & & & & $\mathrm{X}$ & & 25 \\
\hline Piperaceae & Piper sp. & $\mathrm{X}$ & & & & & 5 \\
\hline Poaceae & $*$ & & & & $\mathrm{X}$ & $\mathrm{X}$ & 22,34 \\
\hline Portulacaceae & Portulaca mundula & & & & $\mathrm{X}$ & & 25,26 \\
\hline Rhamnaceae & Condalia microphylla & & & $\mathrm{X}$ & & & 13 \\
\hline Rhamnaceae & Ziziphus oblongifolius & & & $\mathrm{X}$ & & & 19 \\
\hline Rubiaceae & $*$ & $\mathrm{X}$ & & & & & 1 \\
\hline Sapindaceae & Paullinia capreolata & & $\mathrm{X}$ & & & & 10 \\
\hline Sapotaceae & Pouteria sp. & $\mathrm{X}$ & $\mathrm{X}$ & & & & 2,11 \\
\hline Sapotaceae & Pouteria egregia & & $\mathrm{X}$ & & & & 10 \\
\hline Sapotaceae & Chrysophyllum prieurii & & & $\mathrm{X}$ & & & 14 \\
\hline Simaroubaceae & Castela coccinea & & & $\mathrm{X}$ & & & 12,19 \\
\hline Simmondsiaceae & Simmondsia chinensis & & & & $\mathrm{X}$ & & 27 \\
\hline Solanaceae & $*$ & $\mathrm{X}$ & & & & & 1 \\
\hline Solanaceae & Solanum viarum & & & & $\mathrm{X}$ & $\mathrm{X}$ & 20,31 \\
\hline Solanaceae & Solanum triquetrum & & & & $\mathrm{X}$ & & 24,25 \\
\hline Solanaceae & Physalis viscosa & & & & $\mathrm{X}$ & & 24 \\
\hline Verbenaceae & Vitex cymosa & & & & $\mathrm{X}$ & $\mathrm{X}$ & 20,31 \\
\hline Verbenaceae & Phyla incisa & & & & $\mathrm{X}$ & & 26 \\
\hline Verbenaceae & Phyla nodiflora & & & & $\mathrm{X}$ & & 26 \\
\hline Vitaceae & Cissus rhombifolia & & & & $\mathrm{X}$ & $\mathrm{X}$ & 23,36 \\
\hline
\end{tabular}

a: An item was considered common when it was found in more than $10 \%$ of the diet, measured as occurrence in stomach contents or feces, independent events of direct observation of foraging, proportion of time spent by a lowland tapir foraging on the plant, percentage of total dry weight of ingested food, or proportion of the item relative to the total number of ingested items. *: Not indentified species. Reference 1: Talamoni and Assis (2009), Semideciduous Tropical Forest, Brazil; 2: Tobler et al. (2010), Peruvian Amazon; 3: Giombine et al. (2009), Semideciduous Tropical Forest, Brazil; 4: Bizerril et al. (2005), Cerrado, Brazil; 5: Santos et al. (2005), Atlantic Forest (Restinga Habitat), Brazil; 6: Galetti et al. (2001), Semideciduous Tropical Forest, Brazil; 7: Henry et al. (2000), Amazonia, French Guiana; 8: Fragoso and Huffman (2000), Amazonia, Brazil; 9: Bodmer (1990), Amazonia, Peru; 10: Gayot et al. (2004), Amazonia, French Guiana; 11: Branan et al. (1985), Amazonia, Suriname; 12: Serbent et al. (2011), Semideciduous Forest, Argentina; 13: Kufner et al. (2008), Chaco Forest, Argentina; 14: Gayot et al. (2004), Amazonia, French Guiana; 15: Pinder (2004), Pantanal, Brazil; 16: Richard and Juliá (2001), Loa Yungas phytogeographic province, Argentina; 17: Richard et al. (1995), Loa Yungas phytogeographic province, Argentina; 18: Branan et al. (1985), Amazonia, Suriname; 19: Stallings et al. (1984), Chaco, Paraguay; 20: Desbiez et al. (2009), Pantanal, Brazil; 21: Keuroglian and Eaton (2008), Semideciduous Tropical Forest, Brazil; 22: Salazar (2007), Savannah, Bolivia; 23: Barreto et al. (1997), Amazonia, Venezuela; 24: Everitt et al. (1981), Arid Environment (Zachry Ranch), EUA; 25: Everitt et al. (1981), Arid Environment (Gonzalez Ranch), EUA; 26: Everitt et al. (1981), Arid Environment (Yturria Ranch), EUA; 27: Eddy (1961), Arizona Desert (Tucson Mountain Park), EUA; 28: Eddy (1961), Arizona Desert (Santa Rita Range), EUA; 29: Eddy (1961), Arizona Desert (Canelo Hills), EUA; 30: Neal (1959), Arizona Desert, EUA; 31: Desbiez et al. (2009), Pantanal, Brazil; 32: Keuroglian and Eaton (2008), Semideciduous Forest, Brazil; 33: Keuroglian et al. (2009), Pantanal, Brazil; 34: Salazar (2007), Savannah, Bolivia; 35: Altrichter et al. (2000), Tropical Wet Forest, Costa Rica; 36: Barreto et al. (1997), Amazonia, Venezuela. 